\title{
ANALISIS YURIDIS PENDEKATAN EMPIRIK DALAM ANTROPOLOGI HUKUM MENURUT PARA AHLI
}

\author{
STIEVEN YEREMI ZAI \\ Email: Stevenyeremi59@gmail.com \\ No BP: 2110003600078 \\ UNIVERSITAS EKASAKTI PADANG
}

\section{A. PENDAHULUAN}

Antropologi Hukum adalah bagian dari antropologi yang mempelajari perilaku hukum masyarakat, budaya hukum masyarakat, dan cara pandangnya terhadap hukum dan produkproduk turunannya. Hukum-hukum itu bukan hanya yang tertulis dan diundangkan oleh pemerintah, tetapi juga hukum yang tidak tertulis dan disepakati masyarakat setempat. Antropologi itu sendiri didefinisikan sebagai suatu ilmu yang mempelajari tentang manusia baik dari segi budaya, perilaku, keanekaragaman, dan lain sebagainya. Istilah antropologi berasal dari Bahasa Yunani, yaitu berasal dari kata anthropos dan logos. Anthropos berarti manusia dan logos memiliki arti cerita, atau kata, atau ilmu. Antropologi mempelajari manusia sebagai makhluk biologis sekaligus makhluk sosial. Antropologi merupakan salah satu cabang ilmu sosial. Ia lahir atau muncul bermula dari ketertarikan orang-orang Eropa yang melihat ciri-ciri fisik, adat istiadat, budaya yang berbeda yang ada pada masyarakat Eropa. Antropologi lebih memusatkan pada penduduk yang merupakan masyarakat tunggal, dalam arti kesatuan masyarakat yang tinggal di daerah yang sama. Antropologi mirip dengan sosiologi tetapi sosiologi lebih menitikberatkan pada pola interaksi masyarakat dan kehidupan sosialnya. Kajian pendekatan dalam metode penelitian hukum sepenuhnya bergantung pada permasalahan dan tujuan penelitian hukum terkait.Jika permasalahan dan tujuan penelitian adalah unsur-unsur hukum ideal atau ius constituendum dan ius constitutum maka kajian pendekatannya bersifat yuridis normatif logika deduktif, bila masuk unsur atau konsep hukum pola perilaku dan pemaknaan sosial, maka kajian pendekatannya bersifat empiris/sosiologis-logika induktif. Di dalam perkembangan antropologi, masalah hukum 
sebenarnya juga sudah pernah ditelaah, walaupun di dalam suatu kerangka kebudayaan yang serba luas. Sarjana-sarjana antropologi seperti Barton, Radcliffe-Brown, Malinowski dan lainnya, pernah memusatkan perhatian pada hukum sebagai suatu gejala sosial-budaya. Sesudah embrio dari antropologi hukum timbul, maka pandangan para sarjana seperti Schapera, Gluckman, Hoebel, Bohannan, Pospisil, Nader dan lainnya mempunyai peranan besar di dalam perkembangan A.H. Menurut Ihromi (1986; 3) relevansi menelaah hukum dari segi antropologi, antara lain adalah: (a). Berkenaan dengan masalah yang dihadapi oleh negara-negara berkembang (tentunya termasuk Indonesia) yang secara budaya bersifat pluralistis dalam cita-citanya mewujudkan unifikasi hukum atau modernisasi hokum; (b). berkenaan dengan kemungkinan munculnya masalah bila warga masyarakat dari lingkungan sukubangsa tertentu masih mempunyai normanorma tradisional yang kuat dan menuntut ketaatan mengenai hal-hal tertentu, sedangkan dalam norma hukum yang sudah tertulis dan berlaku secara nasional, hal hal yang harus ditaati itu justru dirumuskan sebagai hal yang terlarang. Secara faktual, masalah-masalah yang dirumuskan ke dalam dua point utama itu sudah terjadi, baik berkenaan dengan munculnya konflik horisontal di pelbagai wilayah, pertikaian antara state (maupun pemda) dengan masyarakat, maupun antar kelompok masyarakat sendiri. Hukum, menurut Benda-Beckmann (1979; 113-114) adalah suatu cara khusus untuk membatasi otonomi anggotaanggota masyarakat. Kebanyakan penulis menyetujui bahwa hukum adalah suatu bentuk pengawasan sosial, itulah mengapa secara esensial sifatnya normatif, dan hal itu merujuk pada apa yang disebut (sebagai) konsepsikonsepsi yang obyektif. Implikasi pendekatan semacam ini adalah: bahwa hukum memberi input kepada pranata pengendalian sosial (apapun variant-nya) dan kemudian kepada rujukan berpikir masyarakat, dan sebaliknya. Hukum, di sisi lain, dapat pula menyebabkan perubahan perangkat berpikir, dan rujukan kemasyarakatan lainnya atau dikenal dalam sosiologi hukum sebagai "law as tool of social engineering". Namun, bila kesemua hal itu berubah (dan pada 
kenyataannya memang selalu demikian), maka hukum pun berubah mengikuti perubahan masyarakat dan lingkungannya.

Ilmu hukum empirik yang disebut juga dengan istilah Sociological Jurisprudence merupakan aliran dalam filsafat hukum yang memberikan perhatian yang sama kuatnya terhadap masyarakat dan hukum sebagai dua unsur utama dalam pemberlakuan hukum.

Istilah empiris artinya bersifat nyata. Jadi, yang dimaksudkan dengan pendekatan empiris adalah usaha mendekati masalah yang diteliti dengan sifat hukum yang nyata atau sesuai dengan kenyataan yang hidup dalam masyarakat. Jadi penelitian dengan pendekatan empiris harus dilakukan di lapangan, dengan menggunakan metode dan teknik penelitian lapangan. Peneliti harus mengadakan kunjungan kepada masyarakat dan berkomunikasi dengan para anggota masyarakat. 


\section{B. PEMBAHASAN}

Kata "empiris" bukan berarti harus menggunakan alat pengumpul data dan teori- teori yang biasa dipergunakan di dalam metode penelitian ilmu-ilmu sosial, namun di dalam konteks ini lebih dimaksudkan kepada pengertian bahwa "kebenarannya dapat dibuktikan pada alam kenyataan atau dapat dirasakan oleh panca indera" atau bukan suatu fiksi bahkan metafisika atau gaib, yang sejatinya berupa proses berfikir yang biasanya hanya dongeng maupun pengalaman- pengalaman spiritual yang diberikan Tuhan tidak kepada setiap manusia dan tidak harus melalui proses penalaran ilmiah suatu hal tertentu dapat diterima kebenarannya, meskipun oleh para ilmuwan kadang dikatakan tidak ilmiah atau an illogical phenomena. Penerimaan terhadap suatu yang bersifat ilmiah biasanya dipredikatkan dengan ungkapan "masuk akal”, sedangkan penerimaan terhadap suatu yang bersifat metafisika dan spiritual biasanya disebut sebagai kepercayaan. Oleh sebab itu, penelitian hukum empiris dimaksudkan untuk mengajak para penelitinya tidak hanya memikirkan masalah-masalah hukum yang bersifat normatif (law as written in book), bersifat teknis di dalam mengoperasionalisasikan peraturan hukum seperti mesin yang memproduksi dan menghasilkan hasil tertentu dari sebuah proses mekanis, dan tentunya hanya dan harus bersifat preskriptif saja, meskipun hal ini adalah wajar, mengingat sejatinya sifat norma hukum yang "ought to be" itu. Selanjutnya cara pandang sebagaimana disebutkan tadi bergeser menuju perubahan ke arah penyadaran bahwa hukum, faktanya dari perspektif ilmu sosial tenyata lebih dari sekadar norma-norma hukum dan teknik pengoperasiannya saja, melainkan juga sebuah gejala sosial dan berkaitan dengan perilaku manusia ditengah-tengah kehidupan bermasyarakat yang unik dan memikat untuk diteliti tidak dari sifatnya yang preskriptif, melainkan bersifat deskriptif. Di sisi lain, mengingat para penstudi hukum sejatinya tidak terlatih melakukan penelitian sebagaimana dimaksud, dan faktanya memang tidak dipersiapkan untuk itu, maka peranan para ilmuan sosial berikut metode- metode 
penelitian bahkan teori-teorinya dibutuhkan oleh sebagian penstudi hukum yang ingin melakukan penelitian di bidang hukum dengan menggunakan pendekatan ilmu sosial (sociolegal research21) maupun disebut dengan penelitian hukum interdisipliner, karena kadangkadang bersentuhan dengan ilmu ekonomi, antropoligi, bahkan ilmu politik dan lain- lain. Jenis penelitian yang dimaksud adalah penelitian hukum empiris atau socio-legal (Socio legal research) yang merupakan model pendekatan lain dalam meneliti hukum sebagai objek penelitiannya, dalam hal ini hukum tidak hanya dipandang sebagai disiplin yang preskriptif dan terapan belaka,23 melainkan juga empirical atau kenyataan hukum. Pendekatan antropologi (hukum) sengaja menggeser pusat perhatian dari aturan-aturan kepada individu atau manusia sebagai aktor yang dalam mengambil keputusan mengenai perilakunya dihadapkan kepada tuntutan-tuntutan dari tatanan hukum yang dihadapinya (Ihromi, 2000: 3). Sejalan dengan itu, Spiertz dan Wiber (1979: 3) menegaskan, bahwa: "But to study the real position of people in relation to law requires a different methodological approach from that used in traditional legal studies. The focus have to swift away from law as a codified or customary set of rules and turn instead to the individual who stands at the intersection point of many different legal domains (dikutip dari Ihromi, 2000). Kajian yang diusulkan tersebut lazimnya disebut sebagai kajian terhadap gejala hukum empiris (law in action).

Dengan demikian, hukum dalam lingkup kajian Antropologi Hukum (selanjutnya ditulis A.H.) ditanggapi sebagai gejala empirik yang terjadi dalam kehidupan masyarakat. Hukum dalam konteks ini tidak ditanggapi seperti halnya para yuris mengkaji hukum (secara dogmatik). Secara umum metode AH adalah sebagai berikut: (a). deskriptif - yakni pemerian gejala hukum empirik dalam masyarakat yang diteliti; (b). ideology (menelusuri aturan normatifnya); (c). telaah kasus (case study method), ditambah dengan metode komparasi (perbandingan). Metode yang satu ini mendorong, antara lain diberlakukannya konsepsi cultural relativism (relativisme budaya). Secara umum filsafat hukum mengkaji nilai-nilai 
hukum, sosiologi hukum, antropologi hukum, psikologi hukum, dan lain-lain serta mengkaji perilaku hukum. Sedang kaidah hukum dikaji oleh bidang yang disebut normwissenschaf atau ilmu tentang kaidah. Titik sentral pengkajian dan penelitian ilmu hukum adalah kaidahkaidah hukum. Ilmu hukum tidak dapat dipisahkan dari kaidah hukum. Tetapi persoalannya adalah dalam posisi dan situasi kaidah hukum yang bagaimana yang menjadi perhatian dari ilmu hukum. Sosiologi hukum dan antropologi hukum mempelajari perilaku hukum sebagai kenyataan hukum. Kedua bidang ilmu hukum ini tidak bisa dilepaskan dari adanya kriteria bahwa perilaku atau kenyataan itu sudah bersifat normatif. Jadi harus ada ukuran bahwa bidang penelitian itu bersifat normatif. Dalam filsafat hukum, nilai-nilai yang dikajipun harus bersifat normatif. Ciri yang umum dari kaidah hukum ialah adanya legitimasi dan sanksi. Tanpa terbagi-bagi ke dalam bidang-bidang kajian, ilmu hukum dengan sendirinya sudah mengkaji nilai, kaidah dan perilaku. Yang berbeda antara satu kajian dengan kajian lain ialah kadar, intensitas atau derajat di anatara ketiga hal tersebut. Konsep mengenai metode dan ilmu bersifat universal. Artinya, untuk bidang apa saja atau untuk jenis ilmu manapun adalah sama, tetapi pengaruh dari obyek suatu ilmu tentu tak dapat dihindarkan. Sebab itu hakekat hukum dan fungsinya dalam praktek tak dapat dihindari berpengaruh dalam menentukan metode yang digunakan dalam ilmu hukum.Apabila melihat hakekat hukum, ilmu hukum tidak didasarkan pada empirisme atau rasionalisme saja, karena gejala hukum tidak hanya berupa hal yang dapat diserap oleh indra atau pengalaman manusia berupa perilaku hukum saja tetapi juga berisi hal-hal yang tak terserap oleh indra manusia, yakni nilai-nilai hukum. Kebenaran yang dapat dicapai oleh ilmu hukum ialah apabila disadari adanya penampakan dari obyek dan seraya menyadari pula arti dibelakang obyek tersebut. Antropologi Hukum merupakan bagian dari Ilmu-Ilmu Sosial. Ia merupakan suatu disiplin ilmu yang berdiri sendiri, karena sudah memenuhi persyaratan sebagai suatu ilmu. Empiris (empirical). Artinya, bahwa Antropologi Hukum merupakan suatu disiplin yang didasarkan atas: 
(a) observasi terhadap kenyataan (social fact)

(b) penggunaan akal sehat (true logic)

(c) hasilnya tidak spekulatif (data based)

Ilmu empiris pada antropologi hukum lebih menitikberatkan pada kenyataankenyataan hukum yang nampak dalam situasi aatau peristwa hukum (law in actions) tidak hukum dalam peraturan perundang-undangan tertulis (law in book). Antropologi hukum sebagai ilmu empiris mempunyai konsekuensi bahwa teorinya harus didukung oleh fakta yang relevan atau setidaknya terwakili secara representatif.

\section{PENUTUP}

Dengan pendekatan empiris bukan berarti tidak ada sama sekali pengertian-pengertian teoritis yang dapat dikemukakan peneliti, namun hanya pokok-pokok pengertian yang telah diketahuinya, yang belum mendalam, dikarenakan si peneliti masih kurang mengetahui dan menguasai teori-teori tersebut. Yang penting dalam pendekatan empiris adalah apa yang dialami dan didapat datanya oleh peneliti di lapangan. Penelitian dengan pendekatan empiris selalu diarahkan kepada identifikasi (pengenalan) terhadap hukum nyata yang berlaku, yang implisit berlaku (sepenuhnya) bukan yang eksplisit (jelas, tegas diatur) di dalam perundangan atau yang diuraikan dalam kepustakaan. Begitu pula diarahkan kepada efektivitas (keberlakuan) hukum itu dalam kehidupan masyarakat. Dari data-data yang dikumpulkan di lapangan, maka dapat diketahui apakah hukum yang diatur di dalam perundangan atau teoriteori yang diuraikan dalam kepustakan hukum, benar-benar berlaku dalam kenyataan, ataukah belum berlaku, tidak berlaku, terjadi penyimpangan, telah berubah dan sebagainya.

Pendekatan antropologi (hukum) sengaja menggeser pusat perhatian dari aturanaturan kepada individu atau manusia sebagai aktor yang dalam mengambil keputusan mengenai perilakunya dihadapkan kepada tuntutan-tuntutan dari tatanan hukum yang dihadapinya. 


\section{DAFTAR PUSTAKA}

Darmini Roza dan Laurensius Arliman S, Peran Pemerintah Daerah Di Dalam Melindungi Hak Anak Di Indonesia, Masalah-Masalah Hukum, Volume 47, Nomor 1, 2018. https://doi.org/10.14710/mmh.47.1.2018.10-21

Laurensius Arliman S, Peranan Metodologi Penelitian Hukum di Dalam Perkembangan Ilmu Hukum di Indonesia, Soumatera Law Review, Volume 1, Nomor 1, 201. http://doi.org/10.22216/soumlaw.v1i1.3346.

Laurensius Arliman S, Peran Badan Permusyawaratan Desa di Dalam Pembangunan Desa dan Pengawasan Keuangan Desa, Padjadjaran Journal of Law, Volume 4, Nomor 3, 2017. https://doi.org/10.15408/jch.v4i2.3433.

Laurensius Arliman S, Penanaman Modal Asing Di Sumatera Barat Berdasarkan UndangUndang Nomor 25 Tahun 2007 Tentang Penanaman Modal, Supremasi Hukum, Volume 1, Nomor 1, 2018. http://dx.doi.org/10.36441/hukum.v1i01.102 .

Laurensius Arliman S, Memperkuat Kearifan Lokal Untuk Menangkal Intoleransi Umat Beragama Di Indonesia, Ensiklopedia of Journal, Volume 1, Nomor 1, 2018, https://doi.org/10.33559/eoj.v1i1.18.

Laurensius Arliman S, Perkawinan Antar Negara Di Indonesia Berdasarkan Hukum Perdata Internasional, Kertha Patrika, Volume 39, Nomor 3, 2017, https://doi.org/10.24843/KP.2017.v39.i03.p03.

Laurensius Arliman S, Partisipasi Masyarakat Di Dalam Pengelolaan Uang Desa Pasca Undang-Undang Nomor 6 Tahun 2014 Tentang Desa, Jurnal Arena Hukum, Volume 12, Nomor 2, 2019, https://doi.org/10.21776/ub.arenahukum.2019.01202.5.

Laurensius Arliman S, Mewujudkan Penegakan Hukum Yang Baik Di Negara Hukum Indonesia, Dialogica Jurnalica, Volume 11, Nomor 1, 2019, https://doi.org/10.28932/di.v11i1.1831.

Laurensius Arliman S, Mediasi Melalui Pendekatan Mufakat Sebagai Lembaga Alternatif Penyelesaian Sengketa Untuk Mendukung Pembangunan Ekonomi Nasional, UIR Law Review, Volume 2, Nomor 2, 2018, https://doi.org/10.25299/uirlrev.2018.vol2(02).1587

Laurensius Arliman S, Peranan Filsafat Hukum Dalam Perlindungan Hak Anak Yang Berkelanjutan Sebagai Bagian Dari Hak Asasi Manusia, Doctrinal, Volume 1, Nomor 2,2016.

Laurensius Arliman S, Ni Putu Eka Dewi, Protection of Children and Women's Rights in Indonesia through International Regulation Ratification, Journal of Innovation, Creativity and Change Volume 15, Nomor 6, 2021.

Laurensius Arliman S, Gagalnya Perlindungan Anak Sebagai Salah Satu Bagian Dari Hak Asasi Manusia Oleh Orang Tua Ditinjau Dari Mazhab Utilitarianisme, Jurnal Yuridis, Volume 3, Nomor 2, 2016, http://dx.doi.org/10.35586/.v3i2.180

Laurensius Arliman S, Tantangan Pendidikan Kewarganegaraan Pada Revolusi 4.0, Jurnal Ensiklopedia Sosial Review, Volume 2, Nomor 3, 2020. 